\title{
Mikä tekee meistä ihmisiä
}

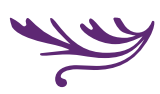

Olin ottamassa verikoetta noin 90-vuotiaasta rouvasta erään vanhainkodin osastolla.

Tehdessäni lähtöä rouva tarttui minua käsivarresta ja pyysi minua jäämään vähäksi aikaa. Sanoin, että valitettavasti minun täytyy lähteä, sillä minulla on vielä paljon verikokeita otettavana. Tähän hän sanoi, että jättäkää edes ovi auki, niin että hän näkisi käytävässä liikkuvia ihmisiä, ja että hänkin saisi olla ihminen. - Ajatuksia herättävä repliikki: "...että saisin olla ihminen". Tämä liikuntakyvytön rouva koki, että hän voi olla ihminen vain toisten ihmisten seurassa.

SUOMALAINEN VÄESTÖ vanhenee kovaa vauhtia. Varsinkin kaikkein iäkkäimpien ihmisten eli yli 80-vuotiaiden lukumäärä kasvaa niin, että vuonna 2020 yli 80-vuotiaita arvioidaan olevan jo yli viis prosenttia väestöstä (Helin 2002, 37) ja heistä vähintään 90-vuotiaita arvioidaan olevan noin 33000 (Jyrkämä 2008, 267). Perinteinen vanhuuden elämänvaihe on pidentynyt ja sitä on ruvettu jakamaan käsitteellisesti eri ikävaiheisiin. On ruvettu puhumaan kolmannesta iästä, varhaisvanhuudesta ja neljännestä iästä, myöhäisvanhuudesta. Myöhäisvanhuudesta aletaan puhua vasta toimintakyvyn merkittävästi heikennettyä (Jyrkämä 2008, 281-282). Kolmannelle iälle (65 vuodesta $80-85$ vuoteen) on tyypillistä hyvän terveydentilan ja aikaisemman elämäntyylin ja harrastusten jatkuminen. (Marin 2008, 21.) Entä neljäs ikä? Cumming'in ja Henry’n 1960-luvulla esittämä irtaantumisteoria vanhojen ihmisten irtaantumisesta erilaisista sosiaalisista pyrkimyksistä on aikansa elä- nyt, mutta ajattelumallina sen vaikutus on voimakas. Itse asiassa se näyttää olevan kuvausta monien neljännessä iässä olevien ihmisten elämästä tänä päivänä. (Johnson 2009, 662, Suutama 2008, 274-275.)

Onko niin, että neljännessä iässä olevien ihmisten persoonallinen kasvu katsotaan jo saavutetun? Länsimaisissa yhteiskunnissa ikääntyvien ihmisten tuntemukset kasvusta ja elämän tarkoituksesta vähenevät. Psykologinen integraatio katsotaan saavutetun jo aivan liian aikaisessa elämänvaiheessa, mikä johtaa ennenaikaiseen identiteetinsulkeumaan ja jättää elämän viimeisten vuosien tehtäväksi status quon säilyttämisen. (Coleman 2000, 292.) Kaikkein iäkkäimmillä ei ole enää merkityksellisiä sosiaalisia rooleja? Korkeaa ikää onkin kutsuttu "roolittomaksi rooliksi", toisin sanoen ajaksi, jolloin ikäihmisiltä ei enää odoteta mitään. (Rowe \& Khan 1999, 51.)

Tiikkainen (2006) on tutkinut vanhuusiän yksinäisyyttä määrittäviä tekijöitä vuorovaikutusteoreet- 
tisesta näkökulmasta. Vanhuusiän yksinäisyydessä erottui emotionaalinen ja sosiaalinen ulottuvuus. Emotionaalista yhteisyyden kokemusta määrittivät ystäväsuhteet ja positiivinen mieliala. Sosiaalista yhteisyyden tunnetta taas määrittivät ystäväkontaktien lisäksi terveyttä ja toimintakykyä kuvaavat muuttujat. (Mt. 55.) Yksinäisyyden tuntemuksia aiheuttaa ikäihmisille se, että ihmissuhteita ei koeta tyydyttäviksi, toisin sanoen niistä ei saada sitä, mitä niiltä odotetaan (Routasalo, Pitkälä, Savikko, \& Tilvis 2003, 30.) Parkkilan, Välimäen \& Routasalon (2000) tutkimuksessa laitoshoidossa olevien ikäihmisten emotionaalinen yksinäisyys ilmeni ikävänä, pahana olona, tarpeettomuuden tunteina ja elämän merkityksettömänä kokemisena. Yksinäisyyden kokemukset olivat yhtäjaksoisia, pitkäaikaisia ja epämiellyttäviä. (Mt. 31.) Myös Kilpi (2010) sai samanlaisen tuloksen omassa tutkimuksessaan: Vanhukset viettivät aikaansa huoneissaan. Ruokailujen yhteydessä olisi ollut mahdollisuus seurusteluun, mutta sen esti asukkaitten huono kuulo ja näkö. (Mt 68.)

Ovaskaisen (2010) tutkimuksessa tulokset olivat samansuuntaisia: Vanhainkodissa asuvat eivät tunteneet toisiaan ja aikaa vietettiin omassa huoneessa televisiota katsellen ja lukien. Ruokailujen yhteydessä saattoi syntyä keskustelua. Toisten huoneissa ei kuitenkaan vierailtu. (Mt. 43-45.) Hauge \& Heggen (2008) tutkimuksessa vanhainkodissa asuvat ikäihmiset tuotiin yhteiseen olohuoneeseen, jossa he viettivät suurimman osan päivää. Seurustelua asukkaitten välille ei syntynyt vaan asukkaat etsivät enemmän kontakteja hoitajiin kuin toisiinsa. Asukastovereita pidettiin liian vanhoina puhumaan eikä yhteisiä keskustelunaiheita löytynyt. (Mt. 460-467.)

Ovatko laitoksissa tai vielä kotona asuvat neljännen iän ihmiset nyky-yhteiskunnan ulkopuolisia ja yhteisöllisyydestä osattomia, oman huoneensa tai vieläkin pienemmän elämänpiirin, oman sänkynsä vankeja? Viime vuosikymmeninä aikuiskasvatus on jättänyt tarkastelunsa ulkopuolelle yhä suuremman osan aikuisen ihmisen elämäntodellisuuden, kasvun ja kehityksen kysymyksistä (Filander 2005, 222). Aikuiskasvatustieteen ei tule unohtaa myöskään neljännen iän ihmisiä. Inhimillinen elämä on jatkumo eikä sitä tulisi pakottaa tiukkoihin ikäryhmiin, sillä ne saavat aikaan vaan eristymistä ja stereotypioita. Ei ole olemassa ikäkautta, joka olisi toista parempi. (Kurki 2008, 18-19.) Filander $(2007,90)$ kysyykin, olisiko sosiaalipedagogiselle asennoitumiselle olemassa sosiaalinen tilaus?

Hoivan tarpeessa olevien ihmisten lukumäärä kasvaa tulevina vuosina. Iän karttuessa oma-aloitteisuus sosiaalisten suhteiden solmimiseen ja hoitamiseen voi vaikeutua. Niinpä lähiympäristössä tarjolla olevat mahdollisuudet yhteisöllisyyden kokemiseen ovat tärkeitä. Minulle oivalluksen lähteenä yhteisöllisyyden kokemisen tutkimisessa toimi Weissin $(1974,1885)$ interaktionistinen teoria sosiaalisen ja emotionaalisen yhteisyyden kokemisen tarpeista. Yksi ihmissuhde ei välttämättä tyydytä kaikkia tarpeita. Sosiaalisen yhteisyyden kokemisessa on tärkeätä arvostuksen kokeminen, liittyminen ja hoivaaminen. Nämä tarpeet täyttyvät, jos yksilö pääsee täysivaltaisesti haluamiensa yhteisöjen jäseneksi. Emotionaalista yhteisyyttä taas määrittävät kiintymys ja neuvojen ja avun saaminen. Läheisten, emotionaalisesti merkityksellisten ihmissuhteiden puuttuminen voi aiheuttaa raastavia yksinäisyyden kokemuksia. (Weiss 1985, 17-19.)

Kokivatko vanhainkodissa asuvat haastateltavani ympärillään olevat mahdollisuudet yhteisöllisyyteen ja sosiaalisten suhteiden solmimiseen riittäviksi ja sosiaalisesti ja emotionaalisesti tyydyttäviksi ja heidän persoonallista kasvuaan vahvistaviksi? Huomioni keskipisteessä olivat ennen kaikkea asukkaitten keskinäiset suhteet ja osallistuminen yhteisyyttä aikaansaavina tekijöinä. Pro gradu -työni sijoittui aikuiskasvatuksen ja sosiaalipedagogiikan alueelle. Sosiaalipedagogiikan tavoitteena on ihmisten auttaminen yhteisöihin liittymisessä. Sosiaalipedagogisen näkökulman mukaan ihminen on samanaikaisesti persoonallinen ja yhteisöllinen. Ehkäpä kasvu yhteisöllisyyteen lähteekin persoonallisen integriteetin säilymisen ja jatkuvan kasvun tukemisesta.

\section{HAASTATELTAVAT JA KONTEKSTI}

Tutkimustani varten haastattelin kuusi ihmistä, jotka olivat iältään 80-97 vuoden välissä. Haastattelut toteutin teemahaastattelulla. Suurin osa heistä liikkui pyörätuolilla. Viisi heistä tarvitsi tuntuvaa apua päi- 
vittäisissä toiminnoissaan. Kognitiiviset toiminnat kaikilla haastateltavilla olivat normaaleja. He olivat asuneet vanhainkodissa puolesta vuodesta reiluun kolmeen vuoteen. Jokaisella oli oma huone ja siellä omat huonekalut. Yhdessä kerroksessa on 8-9 asukashuonetta, yhteinen ruokailutila, pieni keittiö ja tilava parveke. Vanhainkodin alakerrassa sijaitsee iso ruokasali, jossa asukkaat söivät lounaan, päivällisen ja joivat päiväkahvin. Aamu- ja iltapala syötiin oman kerroksen ruokailutilassa. Alakerran ruokasalissa järjestettiin yhteinen ohjelma, mm. hartaus- ja musiikkituokioita sekä juhlatilaisuudet. Vanhainkodin pohjakerroksessa on kerhohuone, kuntosali ja saunatilat. Vanhainkodilla on myös pieni piha-alue, jossa pari kertaa kesässä järjestetään kahvi- ja letunpaistohetkiä. Nyttemmin vanhainkodin nimike on muuttunut tehostetun palveluasumisen ryhmäkodit -nimikkeeksi.

\section{TEOREETTISET LÄHTÖKOHDAT}

Sosiaalipedagogiikassa sosiaalista kasvatusta toteutetaan sosiokulttuurisen innostamisen avulla. Innostamisessa on kolme ulottuvuutta: Pedagogisen toiminnan kautta pyritään tukemaan yksilön persoonallista kasvua, motivoitumista ja asenteiden muuttumista. Sosiaalinen ulottuvuus keskittyy yhteisön vahvistamiseen ja toiminnan päämääränä on persoonien yhteen saattaminen ja yhteisten kokemusten jakaminen. Kulttuurinen ulottuvuus keskittyy luovuuden ja ilmaisun kehittymiseen (musiikki, taide, käsityöt, kirjallisuus). Joku näistä ulottuvuuksista voi olla etusijalla, kaikki ovat kuitenkin mukana. Kyse ei ole interventioista vaan nimenomaan osallistavasta toiminnasta. Innostaminen on tietoista kasvatuksellista toimintaa, jonka tavoitteena on ihmisten elämänlaadun parantaminen. Olennainen tekijä elämänlaadun paranemisessa on, että ihmiset voisivat olla oman elämänsä subjekteja, aktiivisia toimijoita ja samalla oppijoita. (Kurki 2000, 19, 14; 2008, 71.) Aikuisten kasvattaja on lähinnä innostaja, vierellä kulkija, joka rohkaisee erilaisten kokemusten vastaanottamiseen ja niiden jakamiseen. Innostaminen ei ole autoritatiivistä ohjelma- ja harrastetuokioiden suunnittelemista ja toteuttamista, joihin ikäihmiset osallistuvat passiivisina mukanaolijoina. Innostajan työkalupakissa on käytännön menetelmiä, joiden käyttöä ohjaavat edellä mainitut kolme ulottuvuutta. (Kurki 2008,9-11,51.)

Yhteisyyden kokemisen lähtökohtana on, että yhteisön jäsenillä on jotakin yhteistä. Yhteisyys ja ryhmäidentiteetti alkavat kehittyä, kun yhteisön jäsenillä on mahdollisuus osallistua ja jakaa kokemuksiaan toistensa kanssa. Osallistuminen tarkoittaa toiminnallista läsnäoloa inhimillisissä suhteissa. (Lehtonen 1990, 23-24; Nivala 2010, 112.) Yhteisöllisen suhteen tunnusmerkkejä ovat integraatio, dialogi, solidaari-

suus, avoimuus, uudistuminen ja

TARPEINA pysyvyys. Integraatio tarkoittaa yksinkertaisesti sitä, että ihmiset tuntevat toisensa ja yhdistävät voimansa. Suhteet nousevat dialogista; jokaisella on tärkeää sanottavaa ja jokaista kuunnellaan. Solidaarisuus tarkoittaa sitä, että toiminnan päämääränä on luoda yhteisön ARVOSTUKSEN KOKEMINEN, LIITTYMINEN JA

HOIVAAMINEN

T̈̈YTTYV̈̈T, JOS

YKSILÖ P ̈̈̈̈SEE

T⿱艹 ŸSIVALTAISESTI

HALUAMIENSA

YHTEISÖJEN

J ̈̈SENEKSI.

Avoimuus antaa mahdollisuuden antamiseen, vastaanottamiseen ja persoonalliseen kasvuun yhteisön jäsenten kesken ja myös suhteissa ympärillä oleviin yhteisöihin. Kun yhteisöllisiin suhteisiin on syntynyt pysyvyyttä, on mahdollisuus jatkuvaan uudistumiseen. (Kurki 2002, 45, 50-51.)

Yhteisöllisissä suhteissa tärkeintä on jakaminen. Jakamisen kautta sekä persoona että yhteisö rakentuvat ja muotoutuvat. Buberin mukaan ihminen voi tulla persoonaksi vain Minä-Sinä -suhteessa, suorassa ja välittömässä yhteydessä toiseen persoonaan. (Värri 2002,71-72.) Jos kohtaamme toisen ihmisen Sinänä, meidän on mahdollista elää yhdessä koettu tapahtuma myös toisen osapuolen näkökulmasta. Tällainen kohtaaminen on dialogista kohtaamista, toisen kuuntelemista ja arvostamista. (Mt. 66-67.) 
Aito yhteisöllisyys syntyy, kun Minä-Sinä -ystävyydet laajenevat kaikkien Sinujen ystävyyteen eli yhteisyyteen. Yhteisön jäsenillä on yhteisiä arvoja ja kokemuksia. (Kurki 2002, 53-54.) Buber puhuu myös Minä-Se -suhteista. Silloin ihminen asennoituu välineellisesti niin itseensä kuin muihinkin ja rajoittaa persoonana olemisen ja kasvun mahdollisuuksia. (Värri 2002, 73-75.)

\section{METODISET LÄHTÖKOHDAT}

Eksistentiaalis-fenomenologisen metodin ihmiskäsityksenä on Rauhalan holistinen ihmiskäsitys, eksistenssi, ja metodi on kehitetty tajunnallisten ilmiöiden tutkimiseen (Rauhala 1993, 69-70). Rauhalan mukaan ihminen on ihminen juuri siksi, että hän on suhteissa oman situaationsa lukemattomiin erilaisiin rakennetekijöihin. Ihmisyksilö reaalistuu kolmessa olomuodossa: orgaanisessa olemisessa, tajunnallisuudessa ja situationaalisuudessa. Niinpä situaatio erilaisine rakennetekijöineen on ontologisessa mielessä ihmistä, sillä orgaaninen oleminen ja tajunnallisuus voivat tulla olemassa oleviksi vain situationaalisuudessa. Termi situationaalisuus johdetaan sanasta situaatio, ja sillä tarkoitetaan sitä todellisuuden tai maailman osaa, johon yksi ihminen on suhteessa. (Rauhala 2005, 95-97.)

Millaisista kokemuksista rakentuu se todellisuus (yhteisöllisyys), jonka keskellä haastateltavani elivät? Fenomenologisessa tutkimuksessa kokemukset rakentuvat niistä merkityksistä, joita annamme elämismaailmassamme eli situaatiossamme oleville asioille ja ilmiöille. Merkitykset eivät ole irrallisia vaan ilmenevät suhteina. Juuri näistä merkityssuhteista muotoutuvat kokemukset ja kokemuksista muodostuu maailmankuvamme. (Rauhala 1993, 15-16, 69-70; Varto 1992, 56.)

Eksistentiaalis-fenomenologinen menetelmä on kaksiosainen: ensimmäisessä osassa muodostetaan yksilökohtaiset merkitysverkostot kaikille haastateltaville ja toisessa osassa yleinen merkitysverkosto tai sen eri tyyppejä. Analyysi alkaa haastatteluaineiston tarkalla lukemisella, sillä vasta kokonaiskäsityksen hahmottumisen jälkeen aineistosta pystytään erottamaan tutkimustehtävän kannalta relevantteja merkityksiä ja merkityssuhteita (Giorgi 1997, 9-22). Samalla on pyrittävä erittelemään omia ennakkokä- sityksiä, jotta pääsisi lähemmäksi sitä, mikä on toisen ainutlaatuinen suhde johonkin asiaan. Tämän jälkeen erotetut merkityssuhteet muutetaan yleiskieliseen muotoon ja samanaiheiset merkityssuhteet sijoitetaan yksittäisen sisältöalueen alle. Lopulta kirjoitetaan synteesi yksilön kokemuksesta.

Analyysin toisessa osassa muodostetaan yleiset merkitysverkostot. Aineistona ovat yksilökohtaiset merkitysverkostot ja analyysivaiheet ovat yhteneviä ensimmäisen vaiheen kanssa. Päämääränä on löytää tutkittavan ilmiön yleisiä rakenteita, toisin sanoen sisältöjä, jotka ovat yhteisiä useammalle kuin yhdelle tutkittavalle.

\section{VANHAINKOTI SOSIAALISEN YHTEISYYDEN} TILANA

Tutkimukseni tuloksina muodostui neljä yleistä merkitysverkostoa: Sopeutuja, Omissa oloissaan viihtyjä, Yksinäinen odottaja ja Omien arvojensa mukaan eläjä. Kukin yksilökohtainen merkitysverkosto (ks. Perttula 2000, 439-440; Lehtomaa 2009, 186.) sisältyy kokonaisuudessaan yhteen tyyppiin. Kahteen tyyppiin (Sopeutuja ja Omissa oloissaan viihtyjä) sisältyy kumpaankin kaksi yksilökohtaista merkitysverkostoa kokonaisuudessaan. Merkityssuhteet voivat tuoda esiin yleisen (tutkittaville, ei muille) taipumuksen tutkittavaa ilmiötä kohtaan (Giorgi 1997, 11). Nämä "tyypittelyt" ovat omia konstruktioitani, joiden avulla tuon esille haastateltavieni keskeisiä merkityksenantoja vanhuuden ja yhteisöllisyyden kokemisessa. Lopuksi olen vielä koonnut neljän yleisen merkitysverkoston keskeiset piirteet taulukkoon 1 .

\section{JULIA - YKSINÄINEN ODOTTAJA}

Luopuminen toimeliaasta elämästä tuotti Julialle tuskan ja ikävän tunteita: Että minkälaista on hyvä vanhuus. Että sais olla terveenä, se kaiken parasta olis. Että pääsis kunnolla liikkuun ja kulkeen vielä. Se olis ihanaa. Julia (nimi on pseudonyymi) kärsi voimakkaasta yksinäisyydestä. Passiivinen osallistuminen erilaisiin ohjelmatuokioihin ei tyydyttänyt sosiaalisen yhteisyyden kokemisen tarpeita. Hän kaipasi päivittäistä kanssakäymistä muiden kanssa, aktiivista arkielämää ja jatkuvuutta. Hän koki vanhainkodin ihmissuhteet väliaikaisiksi. 
HJA: Onko sulla täällä ketään, jota sä voisit sanoa ystäväksi.

No mä nyt tiedä, kai on tommosia väliaikasia, siinä on semmosta päiväpuhelua, mutta ei semmosta kun ystävä olisi. (Julia, Yksinäinen odottaja)

Julia olisi halunnut oppia tuntemaan omassa kerroksessa asuvat toiset ikäihmiset ja hoitajat kunnolla. Ihmisympäristö oli hänelle fyysistä ympäristöä tärkeämpi: Kyllä täällä on paljon hoitajia ainakin. Niissä on nuoria. Ei ne paljon pysähtele puheille. ... kyllä nuoretkin osaa jutella vanhusten kanssa. Hän ei jaotellut ihmisiä iän mukaan ja oli valmis solmimaan ihmissuhteita kaiken ikäisten kanssa. Hän oli yrittänyt tutustua toisiin ihmisiin ja oli käynyt vieraisilla naapureiden luona, mutta: No joskus jotain, mutta sitten kun ei toisetkaan käy, niin sitä on niin nolo mennä sitten sinne kylään.

Hän kaipasi ihmissuhteita, jotka olisivat tuoneet hänelle turvallisuuden ja johonkin kiinnittymisen tunteita. Tämä kaipaus sai hänet jatkuvasti tarkkailemaan toisten ihmisten potentiaalisuutta ystäviksi. Julia toivoi, että hän saisi olla ihminen, persoona, toisten persoonien yhteydessä. Julia kaipasi myös toimeliaisuutta arkipäiviin. Hän ei harrastanut lukemista, sillä hän oli luonteeltaan tekijä. Hän oli ollut aikoinaan keittiöllä töissä ja ollut juhlapitojen laittaja.

HJA: ... oot etevä ruuanlaittaja. Onko täällä ollu mahdollisuus harrastaa ruuanlaittoa?

Ei täällä, jouluksi leivottiin vähän ja semmosta. Ei sinänsä mitään, kun omassa huushollissa, kun vieraalle laitettiin niin. (Julia, Yksinäinen odottaja)

Hän pystyi käyttämään vain toista kättään, mutta yhdelläkin kädellä pyörätuolissa istuen pystyisi tekemään paljon. Granfelt $(1998,105)$ kirjoittaa, että osallistuminen johonkin itselle merkitykselliseen toimintaan antaa kokemusta omasta paikasta ja omasta osaamisesta. Keittiö oli aikoinaan ollut Julialle emotionaalisesti ja myös sosiaalisesti merkityksellinen paikka. Se ei ollut hänelle pelkkä spatiaalinen tila vaan eletty, kokemuksellinen tila.

\section{ANNA JA LEEA - SOPEUTUJAT}

Annan mielestä vaikeinta vanhuudessa on hyväksyä oman autonomian menetys ja riippuvuus toisista. Hän ei haluaisi enää elää montaa vuotta. Hän on valinnut selviytymiskeinokseen sopeutumisen, koska muutakaan mahdollisuutta ei ole. Rowe \& Kahn $(1999,37)$ puhuvat siitä, että yksi onnistuneen vanhenemisen edellytyksistä on toimintakyvyn säilyttäminen. Anna olisi halunnut olla aktiivinen toimintakykynsä ylläpidossa ja yrittää kävellä rollaattorin kanssa ja harjoituttaa lihaksiaan. Hoitajilla ei kuitenkaan ollut aikaa kulkea vierellä tukemassa, niinpä ei ollut muuta mahdollisuutta kuin jäädä pyörätuoliin. Vanhainkodissa oli mahdollisuus saada fysioterapeutin antamaa kuntoutusta, mutta jokapäiväisen elämän toiminnoissa valittiin nopein tapa toimia.

Annan oli vaikea liikkua ja kuulla. Hän oli käynyt vieraisilla toisten asukkaitten luona, mutta kuulo-ongelmat toivat mukanaan turhautuneisuutta. Ehdotin hänelle, että hänen pitäisi hankkia kuulolaite. Hän vastasi, että: En mä nyt vielä, kun mä oon nähny, että se täytyy niin kauheesti säätää. Anna kertoo, että keskinäistä seurustelua tulee oman kerroksen ruokailutapahtumissa.

HJA: No tutustuuko täällä toisiin ihmisiin, toisiin asukkaisiin?

No ainakin tuossa, me syödään aamupala arkipäivisin ja kahvi, tai se iltapala on, tossa, niin kyllä me aina siinä seurustellaan. (Anna, Sopeutuja)

Hänellä ei kuitenkaan ole yhtään ystävää vanhainkodissa. Hän sanoo ajan kuluvan muutenkin. Hän on sopeutunut huonon kuulon mukanaan tuomaan yksinäisyyteen. Anna oli harrastanut aikaisemmin kansantanssia, kaupoissa kiertelyä ja kukkien hoitoa ja Leea matkailua. Vanhainkodissa olikin ollut aktiivinen matkakerho, mutta sen toiminta oli nyt hiipunut lähes olemattomiin.

Mutta tota sillon, ku vielä se oli isommassa muodossa, mehän tehtiin noita käsinmaalattuja T-paitoja, kuvioita ja kaikkee tämmöstä. Me oltiin sillon vielä kaikki paremmassa kunnossa. ... Ei semmoset meiltä enää onnistu, semmoset hommat. Eikä yhdellä 
kädellä voi tehdä sellasta. Mutta kivahan on nähdä ja jutella. (Leea, Sopeutuja)

Van't Leven \& Jonsson (2002) kirjoittavat, että toimintakyvyn rajoituksien ei tarvitse olla este merkityksellisten harrastusten jatkumiselle. Osallistumista voi toteuttaa kahdella tavalla: ne, jotka pystyvät, tekevät itse ja ne, jotka eivät pysty tekemään mitään, ovat kuitenkin tekemisen ilmapiirissä. Keskellä tekemisen kontekstia oleminen antaa myös tyydytystä tekemisen tarpeelle ja samalla auttaa ikäihmistä pitämään kiinni identiteetistään. (Mt. 148-155.)

Leea kertoo, että vanhainkodissa ei ole totuttu seurusteluun.

\section{HJA: Mikä täällä semmosta tutustumista vaikeuttaa?}

En mä osaa tuohon asiaan sanoa kyllä mitään. Me mennään ruokasaliin ja tullaan pois sieltä ja jos siellä on jotain ohjelmaa niin ollaan siellä ja tullaan pois.

HJA: Mutta ei oo sitten sitä keskinäistä seurustelua?

Ei ole, ehkä se on niin, että ne, jotka tänne on tullu, ne on seurustelunsa seurustellu. Ei niitä ystäviä sillä tavalla niitetä, kuin jotain ruohoo niityllä. (Leea, Sopeutuja)

Leean lausumissa on lohduttomuutta eikä hänellä ole enää suurempia odotuksia elämän suhteen. Hänen mielestään pelkästään osallistumalla johonkin toimintaan ei rakenneta ystävyyssuhteita.

Kesällä pihalla tai parvekkeella oleminen oli iloa tuottava asia kaikille haastateltaville. Piha oli kaikille yhteistä aluetta ja siellä saattoi tuntea olevansa autonominen toimija. Oman paikkansa pihalla voi itse valita ja hakeutua oma-aloitteisesti juttusille toisten kanssa. Itsenäisen liikkumisen parvekkeelle estää kuitenkin kynnys, jonka yli he eivät pyörätuolilla pääse yksin.

HJA: Tuleeko siellä (pihalla) juteltua toisten kanssa?

Kyllä. Siellä tulee juteltua, kun ei kaveria oo toisellakaan niin sitten me istutaan. (Julia, Yksinäinen Odottaja)

\section{OULA JA RAIJA - OMISSA OLOISSAAN VIIHTYJÄT}

Oula ikävöi asioita, jotka aikaisemmin kuuluivat elä- mään. Korkea ikä on tuonut mukanaan paljon luopumista eikä elämälle enää aseteta lähitulevaisuutta pitemmälle meneviä päämääriä. Hän haluaa kuitenkin osallistua virike- ja kuntouttavaan toimintaan: Siinä se samalla niinkun kehittää itseänsä ja koettaa ylläpitää niitä ratkaisun kykyjä, mitä on. Hän on surullinen siitä, että vanhoja ihmisiä ei arvosteta. Hänelle on tärkeää se, että hänen toiveensa otetaan huomioon eivätkä toiset käytä häneen valtaa, joka ei heille kuulu.

Oulalle oma perhe ja lapset ovat tärkeitä. Lähiomainen käy tapaamassa häntä lähes päivittäin ja se riittää hänelle. Tämä voimakas tunneside on kantava voima hänen elämässään: ... Minulla käy täällä aina, lähiomainen käy tapaamassa sillon tällön, aika usein ja tuota. Että ei siinä mielessä yksinäisyys, tartte kärsiä. Ihmissuhteet, jotka perustuvat kiintymykselle, antavat tunteen turvallisuudesta ja paikasta. (Weiss 1974, 23.) Niinpä Oulalla oli sisäisiä voimavaroja myös nauttia yksinolosta ja suuntautua mieluisiin harrastuksiin. Television katsominen ja lukeminen olivat rentouttavaa ja mielenrauhaa tuovaa puuhaa: No mulla on tuolla, mä luen jopa Raamattuakin niin. Se on mun mielestä hyvin antoisa kirja. Emotionaalisen hyvinvoinnin merkitys kasvaa fyysisten ja sosiaalisten rajoitteiden lisääntyessä. Ikäihmiset pyrkivätkin käyttämään kognitiivista kontrollia parantaakseen emotionaalista tilaansa. (Kryla-Lighthall \& Mather 2009, 324.) Oulalle tiiviit, lähes päivittäiset yhteydet lähiomaiseen ja mieluisat harrastukset antoivat tekemistä tarpeeksi, niin että hänellä ei ollut enää suurta tarvetta kutsua toisia kylän tai käydä itse kylässä.

HJA: Joo, entä onko Sinulla juttuseuraa sillon kun haluat?

Kyllä täällä, ilman sitä seuraa tarvitse olla. Jos on niin puhelias, että täytyy jatkuvasti jutella. Mieluummin oon hiljaa kun puhelias. (Oula, Omissa oloissaan viihtyjä)

Pääasiallisimmat ajanvietteet kaikilla haastateltavillani olivat television katsominen ja lukeminen. Raija viihtyi myös paljon omissa oloissaan televisiota katsellen. Hänelle musiikki oli asia, joka oli tuonut elämään iloa ja voimaa jo vuosikymmenien ajan. Nyt hän ei enää kyennyt itse hankkimaan musiikkikokemuksia niin paljon kuin olisi halunnut. 
... On kitaristia ja sitten on laulajia, jotka käy täällä ja joiden musiikki on hyvää, ettei se ole semmosta ala-arvosta.

... Kun musiikki on yks semmonen, mitä mä ainakin kaipaan täälä. Mä en osaa edes radioo käyttää niin paljoo, että minä saisin sieltä...

... Sibeliuksen niistä sävellyksistä mä tykkään. Mä tykkään, että siinä on voimaa. (Raija, Omissa oloissaan viihtyjä)

Ikääntyminen ei muuta ihmistä. Pikemminkin ihminen pyrkii tulemaan yhä enemmän sellaiseksi kuin on aina ollut. (Agahi, Ahacic \& Parker 2006, 340-346.) Välimäki (1997) jatkaa edellistä ajatusta ja kirjoittaa, että minuuden tunnistuksen ja verifioinnin periaate on oleellinen piirre kaikessa merkittävässä yksilöiden välisessä, mutta myös yksilön ja yhteisön välisessä vuorovaikutuksessa. (Mt. 70.)

\section{HILMA - OMIEN ARVOJENSA MUKAAN ELÄJÄ}

Hilma eli mielestään hyvää vanhuutta, sillä hän liikkui itsenäisesti rollaattorin avulla ja muutenkin hänellä oli paljon toimintakykyä jäljellä. Kontaktit toisiin asukkaisiin ja hoitajiin olivat hänelle tärkeitä. Hän kuitenkin koki jäävänsä liian vähälle huomiolle: $M i$ nullahan ei käy hoitaja sen takia, että mä itte toimin. Tosiaan, mä sitten saankin täältä vähän.

Hilmalla oli tiiviit yhteydet lapsiinsa, ja nämä läheiset ihmissuhteet antoivat hänelle emotionaalista turvaa. Usko Jumalaan ja lähellä oleva pääseminen Jumalan luokse antoivat hänelle luottamusta ja voimaa arkipäivän elämään. Hänellä oli voimakas sosiaalisen liittymisen tarve ja niinpä hän hakikin samanlaisen elämänkatsomuksen omaavia ystäviä. Hänellä oli tarve jakaa hengellisiä kokemuksiaan ja ajatuksiaan toisten kanssa.

HJA: Onko täällä toista sellaista asukasta, jonka kanssa sä koet, että sä oot samalla aaltopituudella?

No on, on. Täallä on yks Hilja, Hilja on mun ystävä oikein. Että hän on tota, hän on uskovainen ...

(Hilma, Omien arvojensa mukaan eläjä)

Hilma olisi halunnut leipoa kakun oman kerroksen keittiössä ja kutsua ystäviään kahville.
... Joskus kutkuttaa niin, että hyvänen aika, kun toi taas teki ihanan kakun toi, se mies siellä televisiossa. Että voikun vois tehdä tossa. ... Sillon joo, kyllä minäkin mielelläni, jos tässäkin kunnossa on. Vaikka kaakun tekisin taikka sillai. ... Kun kahvia mulla on täällä ja pannu. (Hilma, Omien arvojensa mukaan eläjä)

Hengelliset asiat ovat olennaisesti kuuluneet hänen elämäänsä vuosikymmenien ajan. Hän lukee Raamattua, hengellisiä lehtiä ja kirjoja. Hän myös toivoisi voivansa kuunnella hengellistä kuoromusiikkia, sillä hän on itse laulanut nuoruudestaan asti hengellisessä kuorossa ja ollut mukana seurakunnallisessa toiminnassa.

Mutta minä oon minä, ja tietysti mä käyn aina tota vähän kurkistamassa, enkä minä kaikkiin paikkoihin aina mene. ...

\section{HJA: Minkälaista ohjelmaa sä toivoisit?}

No minä toivosin, että kävis nuo kuorot, noita ihania hengellisiä lauluja laulaisivat että. Täällä ei oo käyny. (Hilma, Omien arvojensa mukaan eläjä)

Hänellä on vahva itsetunto, sillä hän on saanut toteuttaa persoonallista kasvuaan haluamallaan tavalla aikaisempina vuosikymmeninä. Niinpä hän sanookin osuvasti, että: minä oon minä. Hän tietää, mitä haluaisi, mutta ei jaksa enää toteuttaa toiveitaan.

\section{MIKÄ TEKEE MEISTÄ IHMISIÄ}

Olen koonnut alla olevaan taulukkoon 1 haastateltavieni kokemusten keskeisiä piirteitä. Kaikki haastateltavani ikävöivät hyvää vanhuutta, johon heidän mielestään kuuluivat toimintakyvyn säilyminen, avun saaminen ajallaan, yhteydet sukulaisiin ja ystäviin, arvostuksen ja kyvykkyyden kokeminen ja viihtyisä ympäristö.

Haastateltavani kaipasivat aikaisempia harrastuksiaan. Heillä olisi ollut kykyjä jatkaa niitä jollakin tavalla, jos heidän kykynsä olisi kartoitettu ja annettu niille mahdollisuus. (ks. Shotton \& Seedhouse 1998, 249.) Van't Levenin \& Jonssonin (2002) tutkimuksen mukaan asuinympäristön ilmapiiri ja kuuluminen ryhmään on itse asiassa tärkeämpää kuin varsinainen tekeminen. Itseä kiinnostaviin aktiviteetteihin 


\begin{tabular}{|c|c|c|}
\hline $\begin{array}{l}\text { Hyvään vanhuuteen kuuluu: } \\
\text { - terveys ja toimintakyky } \\
\text { - riittävästi henkilökuntaa } \\
\text { - yhteydet sukulaisiin ja ystäviin } \\
\text { - arvostuksen kokeminen } \\
\text { - viihtyisä ympäristö }\end{array}$ & $\begin{array}{l}\text { Osallistuminen: } \\
\text { - osallistumisen passiivisuus } \\
\text { - aikaisempien harrastusten } \\
\text { jatkumattomuus / jatkuminen } \\
\text { - kuulo- ja liikkumisvaikeudet }\end{array}$ & $\begin{array}{l}\text { Vuorovaikutus: } \\
\text { - emotionaalinen ja sosiaalinen yksinäisyys } \\
\text { yhteisön keskellä } \\
\text { - myönteinen yksinäisyys on antoisaa } \\
\text { - keskinäinen seurustelu ja } \\
\text { ystävyyssuhteet ovat tärkeitä } \\
\text { - kesäaika antaa parempia } \\
\text { mahdollisuuksia yhteisöllisyyteen }\end{array}$ \\
\hline
\end{tabular}

Taulukko 1: Merkitystihentymät sisältöalueittain

voi osallistua monella tavalla henkisesti. Tekemisen ilmapiirissä oleminen koettiin laadullisesti samanlaiseksi tai lähes samanlaiseksi kuin itse tekeminen.

Vanhainkodeissa järjestetään paljon erilaista ohjattua toimintaa, mutta tulevatko osallistujien emotionaaliset ja sosiaaliset tarpeet tyydytetyiksi niiden kautta. Osallistuminen erilaisiin harrastuksiin voidaan käsittää osallistumiseksi erilaisiin sosiaalisiin maailmoihin. Vuosikymmeniä kestäneestä osallistumisesta johonkin sosiaaliseen maailmaan on saattanut tulla olennainen identiteetin rakennusaine. Tietoisuus omasta lähestyvästä kuolemasta voi vielä vahvistaa halua säilyttää yhteys merkityksellisiin sosiaalisiin maailmoihin. (Unruh 1983, 176, 178.) Jatkuvuus tuo elämään hyvinvointia ja persoonallista kasvua, mutta myös yhteisöllisyyttä. Tällaista läpi elämän kulkenutta osallistumista johonkin sosiaaliseen maailmaan voitaisiin myös kutsua elämän aikana kertyneeksi henkiseksi perinnöksi. Sosiaalipedagogiikassa tuetaan ihmistä arvostamaan itseään ja elämän aikana kertynyttä henkistä perintöä. (Kurki 2008, 36.)

Kun yksilöllä on mahdollisuus ylläpitää ja rakentaa omaa identiteettiään, hänen on helppo löytää yhteistä tekemistä ja keskustelunaiheita yhteisön muiden jäsenten kanssa. Samalla hänellä on mahdollisuus tuoda esiin osaamistaan ja kyvykkyyttään niiltä elämän alueilta, joista hän on kerännyt kokemusta kenties jo vuosikymmenien ajan. Mahdollisuus tuoda esille kyvykkyyttään antaa kokemuksen siitä, että on arvostettu. Arvostuksen tunteet antavat tunteen omasta paikasta toisten joukossa. Osallistuminen arkielämään ja itseä kiinnostavaan toimintaan rakentaa ihmissuhteita luonnollisesti ja huomaamat- ta. Passiivisessa ohjelmien seuraamisessa ikäihmisillä ei ole mahdollisuutta jakaa kokemuksiaan eikä toisia opita tuntemaan.

Kuinka vanhainkodissa tai tehostetun palveluasumisen ryhmäkodeissa arkipäivän elämä tulisi järjestää, että asukkaiden sosiaaliset ja emotionaaliset tarpeet tulisivat tyydytetyiksi? Laitoksessa sosiokulttuurisen innostamisen alaan tulisi kuulua kaikki, mitä laitoksessa tehdään. Asukkaitten sosiaalista elämää, autonomian säilymistä ja valintojen tekemisen mahdollisuuksia tulisi pyrkiä tukemaan kaikissa arkielämän toiminnoissa. Jotta tämä olisi mahdollista, henkilökunnan on tunnettava asukkaitten aikaisempaa elämäntapaa ja entisiä ja nykyisiä mielenkiinnon kohteita. (Kurki 2008, 100.)

Yhteisöllisyyden kehittäminen ei näytä onnistuvan sillä tavalla, että ikäihmiset kootaan erilaisiin harrastusryhmiin ja käydään suoraan harrastustoimintaan. Minkä tahansa ryhmätoiminnan alussa tulisi käyttää aikaa tutustumiseen ja ryhmän koheesion vahvistamiseen. Koheesiolla tarkoitetaan jäsenten tuntemaa vetovoimaa ryhmäänsä kohtaan. Ryhmätoiminnan alussa tehtäväkoheesio voi olla etualalla, mutta myöhemmin sosiaalisen koheesion merkitys kasvaa ryhmän jäsenten oppiessa tuntemaan toisiaan. (Kataja, Jaakkola \& Liukkonen 2011,20.) Tutkimukseni kohteessa olleessa vanhainkodissa kokoontui mm. aivojumppa-, kirjanluku- ja elämäkertaryhmiä. Kaikki edellä mainitut ovat itsessään tarpeellista toimintaa. Tutkimukseeni osallistuneet olisivat kuitenkin halunneet seuraavanlaisia ryhmiä: klassisen ja hengellisen musiikin ryhmä, kukkienhoito-, ruuanlaitto- ja leipomisryhmä, raamattu- ja ruko- 
uspiiri. Jos yhteisöllisyyttä lähdettäisiin kehittämään ottamalla huomioon yhteisön jäsenten elämän aikana kertyneet vahvuudet, kyvykkyydet ja osaaminen, yhteisöllisyys syntyisi luonnollisesti ja huomaamatta. Yhteisistä kiinnostuksen kohteista on helppo puhua.

Mitä haastattelemani ihmiset tarvitsisivat persoonallisen kasvunsa, ihmisyytensä tukemiseksi? Heidän mielestään erilaisia ohjelmanumeroita oli tarpeeksi. Mikä siis puuttui? Yhteisöllinen arkielämä puuttui. Henkilökunta teki kaiken eikä asukkaille edes tarjottu mahdollisuutta olla henkilökunnan apuna tekemässä jokapäiväiseen yhteisölliseen elämään liittyviä askareita. Yhteiseen olohuoneeseen tarvittaisiin houkuttelevia tekijöitä: esim. musiikkia, äänikirjoja, lehtiä, lautapelejä, askartelutarvikkeita, maalaustarvikkeita. Arkipäivän tulisi koostua asukkaita kiinnostavasta toiminnasta. Tämä edellyttää ympäristöltä sellaista vuorovaikutusta ja toimintaa, johon yksilö kykenee ottamaan osaa
(Nivala 2010, 114). Tämä ei onnistu ilman henkilökuntaa, jolla olisi aikaa olla rakentamassa asukkaitten kanssa yhteisöllistä elämää yhteisön omista lähtökohdista käsin. Ilman osallistumista yhteisyyden ja johonkin kuulumisen kokemuksia ei synny.

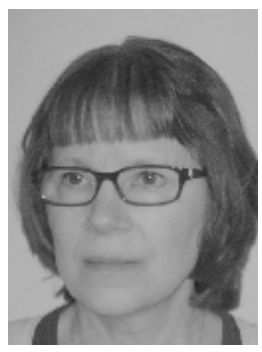

Irene Toivanen

KM, laboratorionhoitaja, Tampere

\section{LÄHTEET}

Agahi, N., Ahacic, K. \& Parker, M. G. (2006). Continuity of leisure participation from middle age to old age. Journal of Gerontology, 61B (6), 340-346.

Coleman, P., G. (2000). Aging and the satisfaction of psychological needs. Psychological Inquiry (2000), 11 (4), 291-293.

Filander, K. (2005). Tutkimuksen muuttuvat tähtäyspisteet. Teoksessa: Heikkinen, A. (toim.) Aikuiskasvatuksen tutkimuspolut. Helsinki: Kansanvalistusseura.

Filander, K. (2007). Sosiaalipedagogiikan uusi ajankohtaisuus. Teoksessa: Hoikkala, T. \& Sell, A. (toim.) Nuorisotyötä on tehtävä: menetelmien perustat, rajat ja mahdollisuudet. Helsinki: Nuorisotutkimusverkosto.

Giorgi, A. (1997). The theory, practice, and evaluation of the phenomenological method as a qualitative research. Journal of Phenomenological Psychology 28 (2), p235, 26p.

Granfelt, R. (1998). Kertomuksia naisten kodittomuudesta. Helsinki: Suomalaisen Kirjallisuuden Seura.

Hauge, S. \& Heggen, K. (2008). The nursing home as a home: a field study of resedents' daily life in the common living rooms. Journal of Clinical Nursing 17 (4), 460-467.
Helin, S. (2002). Palvelujärjestelmä iäkkään ihmisen voimavarojen tukijana. Teoksessa: Heikkinen, E. \& Marin, M. Vanhuuden voimavarat. Helsinki: Tammi.

Johnson, M.L. (2009). Spritituality, finitude, and theories of the life span. Teoksessa: Bengtson, V., Gans, D., Putney, N. M. \& Silverstein, M. Handbook of theories of aging. Second edition. New York: Springer Publishing Company.

Jyrkämä, J. (2008). Vanheneminen ja vanhuus. Teoksessa: Sankari, A. \& Jyrkämä, J. (toim.) Lapsuudesta vanhuuteen. län sosiologiaa. Tampere: Vastapaino.

Kataja, J., Jaakkola, T. \& Liukkonen, J. (2011). Ryhmä liikkeelle. Toiminnallisia harjoituksia ryhmän kehittämiseksi. Jyväskylä: PS-kustannus.

Kilpi. L. (2010). "Tää hioo ihmisestä sen terävimmän kärjen." Narratiivis-sosiaaligerontologinen tutkimus oman kodin jättämisestä ja vanhuudesta vanhainkodissa. Pro gradu -tutkielma: Tampereen yliopisto: Yhteiskuntatieteellinen tiedekunta / Porin yksikkö / sosiaalipolitiikka, Pori. http://tutkielmat.uta.fi/pdf/gradu04261.pdf

Kryla-Lighthall, N. \& Mather, M. (2009). The role of cognitive control in older adults' emotional well-being. Teoksessa Bengtson, V., Gans, D., Putney, N. M. \& Silverstein, M.. Handbook of theories of aging. Second edition. New York: Springer Publishing Company. 
Kurki, L. (2000). Sosiokulttuurinen innostaminen: muutoksen pedagogiikka. Tampere: Vastapaino.

Kurki, L. (2002). Persoona ja yhteisö. Personalistinen sosiaalipedagogiikka. Jyväskylä: Jyväskylän yliopisto.

Kurki, L. (2008). Innostava vanhuus. Helsinki: Oy Finn Lectura $\mathrm{Ab}$.

Lehtomaa, M. (2009). Fenomenologinen kokemuksen tutkimus: haastattelu, analyysi ja ymmärtäminen. Teoksessa Perttula, J. \& Latomaa, T. Kokemuksen tutkimus. Merkitys-Tulkinta-Ymmärtäminen. Rovaniemi: Lapin yliopistokustannus.

Lehtonen, H. (1990). Yhteisö. Tampere: Vastapaino.

Leinonen, A. (2009). Hoivatyöntekijöiden muutostoiveet tulevaisuudelle. Teoksessa: Kröger, T., Leinonen, A. \& Vuorensyrjä, M. Hoivan tekijät. Suomalainen hoivatyö pohjoismaisessa tarkastelussa. Jyväskylä: Jyväskylän yliopisto: Sosiaalityön julkaisusarja 6.

Marin, M. (2008). Tarkastelukulmia ikään ja ikääntymiseen. Teoksessa: Sankari, A. \& Jyrkämä, J. (toim.) Lapsuudesta vanhuuteen. län sosiologiaa. Tampere: Vastapaino.

Nivala, E. (2010). Osallistuminen sosiaalipedagogisen toiminnan periaatteena. Sosiaalipedagoginen aikakauskirja, vuosikirja 2010, vol. 11, 111-122.

Ovaskainen, S. (2010). Omatoimisena ja apua tarvitsevana - Vanhuksen elämä ja toimijuus vanhainkodissa. Pro gradu -tutkielma: Tampereen yliopisto: Yhteiskuntatieteellinen tiedekunta / Sosiaalitutkimuksen laitos / Sosiaalipolitiikka. http://tutkielmat.uta.fi/pdf/gradu04285.pdf.

Parkkila, M., Välimäki, M. \& Routasalo, P. (2000). Kuvaileva tutkimus pitkäaikaisessa laitoshoidossa olevan potilaan yksinäisyydestä. Hoitotiede 12 (1), 26-35.

Perttula, J. (1995). Kokemus psykologisena tutkimuskohteena. Johdatus fenomenologiseen psykologiaan. Tampere: Suomen fenomenologinen instituutti.

Perttula, J. 1996. Deskriptio ja tulkinta: psykologin avaimia kokemukseen. Psykologia 31, 9-18.

Rauhala, L. (1993). Eksistentiaalinen fenomenologia hermeneuttisen tieteenfilosofian menetelmänä. Tampere: Tampereen yliopisto.

Rauhala, L. (1994), julkaistu 1995. Tajunnan ongelma. Kirjassa: Fenomenologinen vuosikirja 1994. Toim. Varto, J. Filosofisia tutkimuksia Tampereen yliopistosta. Tampere: Suomen fenomenologinen instituutti.
Rauhala, L. (2005). Hermeneuttisen tieteenfilosofian analyyseja ja sovelluksia. Helsinki: Yliopistopaino.

Routasalo, P., Pitkälä, K., Savikko, N. \& Tilvis, R. (2003). Ikääntyneiden yksinäisyys. Kyselytutkimuksen tuloksia. Geriatrisen kuntoutuksen tutkimus- ja kehittämishanke. Tutkimusraportti 3. Helsinki: Vanhustyön keskusliitto.

Rowe, J. W. \& Kahn, R. L. (1999). Successful aging. New York: Dell Publishing a division of Random House.

Shotton, L \& Seedhouse, D. 1998. Practical dignity in caring. Nursing Ethics 5 (3), 246-255.

Suutama, T. (2008). Muisti ja oppiminen. Teoksessa: Heikkinen, E. \& Rantanen, T. (toim.) Gerontologia. Helsinki: Duodecim.

Tiikkainen P. (2006). Vanhuusiän yksinäisyys. Seuruututkimus emotionaalisista ja sosiaalisista yksinäisyyttä määrittävistä tekijöistä. Akateeminen väitöskirja: Jyväskylän Yliopisto: Studies in sport, physical education and health, 114, ISSN 0356-1070, ISBN 951-39-2447-5.

Unruh, D. (1983). Invisible lives. Social worlds of the aged. Beverly Hills: Sage.

Van't Leven, N. \& Jonsson, H. (2002). Doing and Being in the Atmosphere of the Doing: Environmental Influences on Occupational Performance in a Nursing Home. Scandinavian Journal of Occupational Therapy 9 (4), 148-155.

Varto, J. (1992). Laadullisen tutkimuksen metodologia. Helsinki: Kirjayhtymä.

Weiss, R. (1974). The Provisions of Social Relationships. Teoksessa Rubin, Z. (toim.) Doing unto others. Englewood Cliffs, NJ: Prentice Hall.

Weiss, R. (1985). Loneliness. The experience of Emotional and Social Isolation. The MIT Press Cambridge, Massachusetts and London, England.

Välimäki, J. (1997). Minuuden ja yhteisön suhteesta. Teoksessa Julma-projekti (toim.). Ajan henki. Antologia minun omista minuuksistani. Tampere: Tampereen yliopisto, tiedotusopin laitos.

Värri, Veli-Matti (2002). Hyvä kasvatus - kasvatus hyvään: dialogisen kasvatuksen filosofinen tarkastelu erityisesti vanhemmuuden näkökulmasta. Elektroninen aineisto: http://helios.uta.fi:2085/ kirjasto/pdf/suoj/VarriHyva.pdf 